\title{
PENINGKATAN EFISIENSI WAKTU KAPAL SANDAR DI ERA NEW NORMAL DIPELABUHAN TANJUNG EMAS SEMARANG
}

\author{
Kumila Hanik $^{1^{*}}$ \\ ${ }^{1}$ Program Studi Transportasi Laut, Politeknik Bumi Akpelni Semarang \\ Jl. Pawiyatan Luhur II/17 Bendan Dhuwur, Gajahmungkur - Semarang 50235 \\ Telp.(024) 8446272 Fax.(024) 8446271 \\ *Corresponding Author. Email:kumila.hanik@akpelni.ac.id. HP: +62 812-9468- \\ 2377
}

\begin{abstract}
Abstrak
Saat ini Bidang Transportasi Laut memiliki tantangan yang cukup berat dikarenakan adanya Covid - 19, sehingga pelayanan terhambat dan kurang maximal terutama dalam sektorindustri perkapalan yang mengharuskan proses penyandaran kapal melalui beberapa prosedur protokol kesehatan. Oleh sebab itu, tujuan dari penelitian ini adalah untuk membahas dan menganalisa tentang masalah yang muncul terkait dengan pelaksanaan penyandaran kapal oleh agen perkapalan dimasa New Normal, dan bagaimana solusi yang diberikan. Metode yang digunakan dalam penelitian ini adalah dengan menggunakan konsep data informasi; kualitas informasi dan nilai informasi.Konsep data informasi adalah data yang diolah menjadi bentuk yang berguna bagi pemakainya.Dari hasil analisa diperoleh bahwa untuk lebih mengefisiensikan waktu sandar, maka para perusahaan pelayaran harus menerapkan kebijakan baru yang dikeluarkan oleh Kementerian Perhubungan Direktorat Jenderal Perhubungan Laut Kantor Kesyahbandaran dan Otoritas Pelabuhan Kelas 1 Tanjung Emas melalui Surat Edaran Nomor UM. 001/09/19/KSOP.Tjng. Emas-2020 Tentang Penetapan Area Karantina Di Dermaga, memberikan panduan dan penerapan protokol kesesehata kepada kapal yang akan sandar dalam aspek kesehatan, sosial, ekonomi dan penanggulangan penyebaran virus corona di wilayah Tanjung Emas Semarang di era new normal.
\end{abstract}

Kata kunci: Transportasi Laut, New Normal, Kebijakan, Efisiensi waktu dan Agency

\begin{abstract}
Currently the Marine Transportation Sector had quite hard challenge due to the existence of Covid - 19, so that services were hampered and not maximal, especially in the shipping industry sector which required the process of anchoring ships through several health protocol procedures. Therefore, the purpose of this study was to discuss and analyze the problems that arose in relation with the implementation of berthing by shipping agents in the New Normal period, and how the solutions were given. The method used in this research was to use the concept of information data; quality of information and value of information.

The concept of information data was a processed data into a useful form to its user.From the results of the analysis, it was found that in order to make berthing time more efficient, shipping companies must implement a new policy
\end{abstract}


issued by the Ministry of Transportation, Directorate General of Marine Transportation, Harbormaster's Office and Port Authority Class 1 Tanjung Emas Port through Circular Number: UM. 001/09/19 / KSOP. Tg Emas - 2020 concerning the Establishment of a Quarantine Area at the quay, provided guidance and application of health protocols for ships that would be berthing in the aspects of health, social, economy and countermeasures for the corona virus spread in Tanjung Emas Semarang area in the new normal era.

Keywords: Marine Transportation, New Normal, Policy, Time Efficiency and Agency

\section{PENDAHULUAN}

Covid 19 adalah Virus Corona atau Severe Acute Respiratory Syndrome Coronavirus 2 (SARS-CoV-2) yang menyerang sistem pernapasan. Virus Corona bisamenyebabkan gangguanringanpada sistem pernapasan, infeksi paru-paru yang berat, hinggamenimbulkankematian. Menurut data yang diperoleh dari Komite Penanganan Covid 19 dan Pemulihan Ekonomi Nasional (KPCPEN) dalam situs (Berita Terkini | Satgas Penanganan Covid-19, n.d.) jumlah terkonfirmasi terpapar Covid 19 sampai dengan tanggal 25 Januari 2021 adalah sebanyak 999.256, sembuh 809.488 dan jumlah pasien meninggal adalah sebanyak 28.132. Semakin hari, kasus ini terus meningkat yang mengakibatkan semua aspek kehidupan dan pekerjaan harus dapat menyesuaikan dengan kebijakan baru pemerintah daerah maupun pusat yang harus dipatuhi khususnya dalam menjalankan protokol kesehatan. Seiring dengan pelaksanaan protokol kesehatan ini, Pemerintah Indonesia menerbitkan protokol normal baru(new normal) bagi pelabuhan dan industri pelayaran dalam menghadapi pandemi virus corona atau Covid-19 yang diatur dalam Implementasi new normal diatur dalam UndangUndang Republik Indonesia Nomor. 6 Tahun 2018 Tentang Kekarantinaan Kesehatan di Pelabuhan pada saat kedatangan kapal dan keberangkatan kapal atau keluar masuk kapal diwilayah pelabuhan harus dalam pengawasan kekarantinaan kesehatan pelabuhan.

Analisanya adalah "Transportasi laut merupakan jalur utama perdagangan Domestic maupun Internasional, dengan semakin ketatnya aturan-aturan dipelabuhan maka akan terjadi penurunan angka expor/impor barang melalui pelabuhan. Namun disaat pandemi seperti saat ini pemerintah berusaha sebaik mungkin untuk tetap menghidupkar roda ekonomi melalui jalur transportasi laut, untuk itu beberapa peraturan telah diterbitkan baik melalui SK Menteri ataupun surat edaran dari lintas Kementrian untuk menunjang tatanan New Normal disemua lini usaha agar masing-masing kebijakan yang telah ditetapkan bisa berjalan dengan baik. Terutama antara Peraturan Direktur Jenderal Perhubungan Laut Nomor HK:103/2/18/DJPL/-16 Tentang Standar Kinerja Pelayanan Operasional pada Pelabuhan yang diusahakan Secara Komersial dengan Undang- 
Undang Republik Indonesia Nomor. 6 Tahun 2018 Tentang Kekarantinaan Kesehatan tentunya akan berpengaruh terhadap kinerja Pelabuhan, namun keselamatan jiwa harus menjadi prioritas.

\section{KAJIAN LITERATUR}

Pelabuhan menurut Pasal 1 Undang-Undang Republik Indonesia Nomor 21 Tahun 1992 , Tentang Pelayaran adalah merupakan tempat yang terdiri dari daratan dan perairan dengan batas-batas tertentu, di mana berlangsung kegiatan pemerintahan dan kegiatan ekonomi. Kegiatan-kegiatan menyangkut kapal-kapal yang bersandar, berlabuh, naik turun penumpang, bongkar muat barang, fasilitas keselamatan pelayaran, serta sebagai tempat perpindahan intra dan antarmoda transportasi.

Transportasi adalah Pemindahan bahan-bahan dan hasil-hasil produksi dengan menggunakan alat angkut dan mengangkut penumpang dari suatu tempat ketempat yang lain. Transportasi sebagai dasar untuk pembangunan ekonomi dan perkembangan masyarakat serta pertumbuhan industrialisasi, Pertumbuhan ekonomi suatu Negara atau bangsa tergantung pada tersedianya pengangkutan dalam Negara. Transportasi laut yaitu suatu sistem pemindahan manusia atau barang yang beroperasi dilaut dengan menggunakan alat sebagai kendaraan dengan bantuan tenaga manusia atau mesin. Transportasi laut memberikan kontribusi yang sangat besar bagi perekonomian nasional dan daerah sebagaimana amanat dalam Undang - Undang No. 17 Tahun 2008 menjadi suatu yang sangat strategis bagi wawasan nasional serta menjadi sarana vital yang menunjang tujuan persatuan dan kesatuan nasional.

Menurut (Salim, 1993), Agen Pelayaran adalah sebuah badan usaha yang bergerak dalam kegiatan atau aktifitas kapal atau perusahaan pelayaran. Apabila suatu kapal berlabuh disuatu pelabuhan maka kapal tersebut membutuhkan pelayanan dan memiliki berbagai keperluan yang harus dipenuhi,. Untuk melayani berbagai keperluan tersebut, perusahaan pelayaran akan menunjuk sebuah agen kapal. Secara garis besar dikenal dengan agen kapal.Agen kapal memiliki 3(tiga) jenis agen yaitu general agent, sub-agent atau agent, dan cabang agen.

Sedang Menurut Peraturan Menteri Perhubungan No. KM.21 Tahun 2007 Tentang Sistem Dan Prosedur Pelayanan Kapal, Barang, Dan Penumpang Pada Pelabuhan Laut Yang Diselenggarakan Oleh Unit Pelaksana Teknis (UPT) Kantor Pelabuhan, 2007: agen umum (general agen) adalah Perusahaan angkutan laut nasional/penyelenggaraan kegiatan angkutan laut khusus yang ditunjuk oleh perusahaan angkutan laut asing diluar negeri untuk mengurus segala sesuatu yang berkaitan dengan kepentingan kapalnya (baik kapal milik, kapal charter, maupun kapal yang dioperasikan).

Saat ini salah satu permasalahan yang sedang dihadapi oleh transportasi laut yaitu di bidang agen sandar kapal. Dikarenakan muncul sebuah virus baru bernamanovel coronavirus (2019-nCoV).Penyakitinidisebabkanolehvirus severe acute respiratory syndrome corona virus2 (SARS-CoV-2) dan dapat menyebabkan 
gangguan sistem pernapasan, mulai dari gejala yang ringan seperti flu, hingga infeksi paru-paru, seperti pneumonia.

\section{METODOLOGI PENELITIAN}

\section{Konsep Dasar Informasi}

Sumber informasi adalah data. Menurut Mustakini (2009), informasi adalah data yang diolah menjadi bentuk yang berguna bagi pemakainya. Informasi merupakan hasil pengolahan dari sebuah model, formasi, organisasi, ataupun suatu perubahan bentuk dari data yang memiliki nilai tertentu, dan bisa digunakan untuk menambah pengetahuan bagi yang menerimanya. Sebuah informasi berisi koleksi fakta yang didapat dari data yang telah terorganisir dengan beberapa cara sehingga dapat memberikan suatu arti yang mampu dipahami oleh penerima.

\section{Metode Penalaran}

Penalaran adalah proses berpikir yang berasal dari pengamatan indera (pengamatan empirik) yang menghasilkan sejumlah konsep dan pengertian. Berdasarkan pengamatan yang sejenis juga akan terbentuk rancangan-rancangan asumsi yang sejenis, berdasarkan sejumlah usulan yang diketahui atau dianggap benar, orang menyimpulkan sebuah asumsi baru yang sebelumnya tidak diketahui. Proses inilah yang disebut menalar. Metode berpikir induktif adalah metode yang digunakan dalam berpikir dengan bertolak dari hal-hal khusus ke umum. Induksi itu sendiri berarti suatu metode yang menyimpulkan pernyataan-pernyataan hasil observasi dalam suatu pernyataan yang lebih umum dan menurut suatu pandangan yang luas diterima. Metode berpikir deduktif adalah metode berpikir yang menerapkan hal-hal yang umum terlebih dahulu untuk seterusnya dihubungkan dalam bagian-bagiannya yang khusus.

\section{HASIL DAN PEMBAHASAN}

A. Kebijakan baru yang diterapkan pada Kementerian Perhubungan Direktorat Jenderal Perhubungan Laut Kantor Kesyahbandaran dan Otoritas Pelabuhan Kelas 1 Tanjung Emas melalui Surat Edaran Nomor UM. 001/09/19/KSOP.Tjng. Emas-2020 Tentang Penetapan Area Karantina Di Dermaga, 2020:

1. Hasil rapat Tim Gugus Tugas Percepatan penanganan Covid -19 di Pelabuhan Tanjung Emas Semarang pada hari Selasa tanggal 13 Oktober 2020 dikantor KSOP Kelas 1 Tanjung Emas.

2. Ditetapkan bahwa untuk sementara Pemeriksaan Karantina oleh Kantor Kesehatan Pelabuhan bagi kapal asing dilaksanakan di Dermaga Samudera dan Dermaga TPKS.

3. Pemberlakuan Surat Edaran hingga tanggal 31 Desember 2020

B. New Normal adalah perubahan perilaku untuk tetap menjalankan aktivitas normal namun ditambah menerapkan Protokol Kesehatan guna mencegah 
terjadinya penularan Covid-19. Penerapan Protokol Kesehatan anti COVID19 diwujudkan dalam pengoperasian angkutan laut meliputi:

Budaya diri sendiri atau Self Independent di atas kapal

1. Jaga kebersihan tangan. Bersihkan tangan dengan cairan pencuci tangan atau hand sanitizer, apabila permukaan tangan tidak terlihat kotor. Namun, apabila tangan kotor maka bersihkan menggunakan sabun dan air mengalir. Cara mencucinya pun harus sesuai dengan standar yang ada, yakni meliputi bagian dalam, punggung, sela-sela, dan ujung-ujung jari.

2. Jangan menyentuh wajah Dalam kondisi tangan yang belum bersih, sebisa mungkin hindari menyentuh area wajah, khususnya mata, hidung, dan mulut.

3. Terapkan etika batuk dan bersin Ketika kita batuk atau bersin, tubuh akan mengeluarkan virus dari dalam tubuh. Jika virus itu mengenai dan terpapar ke orang lain, maka orang lain bisa terinfeksi virus yang berasal dari tubuh kita.

4. Pakai masker Bagi Anda yang memiliki gejala gangguan pernapasan, kenakanlah masker medis ke mana pun saat Anda berada di atas kapal atau berinteraksi dengan orang lain.

5. Jaga jarak Untuk menghindari terjadinya paparan virus dari orang ke orang lain, kita harus senantiasa menjaga jarak dengan orang lain minimal 1 meter.

6. Isolasi mandiri Bagi Anda yang merasa tidak sehat, seperti mengalami demam, batuk/pilek/nyeri tenggorokan/sesak napas, diminta untuk secara sadar dan sukarela melakukan isolasi mandiri di dalam ruangan kapal.

7. Jaga kesehatan Selama berada di dalam kapal atau berkegiatan di luar kapal, pastikan kesehatan fisik tetap terjaga dengan berjemur sinar matahari pagi selama beberapa menit, mengonsumsi makanan bergizi seimbang, dan melakukan olahraga ringan diatas kapal.

C. Sesuai dengan Undang-Undang Republik Indonesia Nomor. 6 Tahun 2018 Tentang Kekarantinaan Kesehatan, Merupakan Tanggung jawab Pemerintah Pusat dan Pemerintah Daerah dalam melindungi kesehatan masyarakat dari penyakit dan/atau Faktor Risiko Kesehatan Masyarakat yang berpotensi menimbulkan Kedaruratan Kesehatan Masyarakat melalui penyelenggaraan Kekarantinaan, dilingkungan pelabuhan.

1. Pada saat kedatangan kapal:

a. Setiap kapal yang datang dari luar negeri, dari pelabuhan wilayah terjangkit didalam negeri atau mengambil orang dan /atau barang dari kapal berada dalam status karantina.

b. Nakhoda memberikan Deklarasi Kesehatan Maritim (Maritime Declaration of Health) Kepada pejabat karantina kesehatan pada saat kapal datang. 
c. Nakhoda hanya dapat menurunkan atau menaikkan orang dan /atau barang setelah dilakukan pengawasan kekarantinaan kesehatan oleh pejabat karantina kesehatan.

d. Pengawasan karantina dilakukan untuk memperoleh persetujuan karantina kesehatan berupa:

1) Persetujuan bebas karantina.

Dalam hal tidak ditemukan penyakit dan/atau faktor risiko yang berpotensi menimbulkan Kedaruratan Kesehatan Masyarakat dan/atau Dokumen Karantina Kesehatan dinyatakan lengkap dan berlaku.

2) Persetujuan karantina terbatas.

Dalam hal ditemukan penyakit dan/atau faktor risiko yang berpotensi menimbulkan Kedaruratan Kesehatan Masyarakat dan/atau Dokumen Karantina Kesehatan dinyatakan tidak lengkap dan tidak berlaku.

2. Prosedure Pengawasan Kekarantinaan Kesehatan di Pelabuhan :

a. Nakhoda menyampaikan permohonan untuk memperoleh Persetujuan Karantina Kesehatan atau memberitahukan suatu keadaan di Kapal dengan memakai isyarat sebagai berikut:

1) Pada siang hari berupa:

a) Bendera Q, yang berarti Kapal saya sehat atau saya minta Persetujuan Karantina Kesehatan;

b) Bendera Q di atas panji pengganti kesatu, yang berarti Kapal saya tersangka;

c) Bendera Q di atas Bendera L, yang berarti Kapal saya Terjangkit; dan

2) malam hari berupa lampu merah di atas lampu putih dengan jarak maksimum 1,80(satu koma delapan nol) meter, yang berarti saya belum mendapat Persetujuan Karantina Kesehatan.

b. Jika dalam waktu berlakunya persetujuan Karantina Kesehatan timbul suatu kematian atau penyakit yang berpotensi menimbulkan Kedaruratan Kesehatan Masyarakat maka Persetujuan Karantina Kesehatan dapat dicabut dan dinyatakan tidak berlaku.

c. Kapal yang Persetujuan Karantina Kesehatannya dicabut dan dinyatakan tidak berlaku wajib menuju ke suatu Zona Karantina untuk mendapat tindakan Kekarantinaan

d. Kapal yang tidak mematuhi peraturan Kekarantinaan Kesehatan tidak diberikan Persetujuan Karantina Kesehatan.

e. Kapal diperintahkan supaya berangkat lagi atas tanggungan sendiri dan tidak diberikan izin memasuki Pelabuhan lain di wilayah Indonesia.

f. Kapal diberikan izin untuk mengambil bahan bakar, air, dan bahan makanan di bawah pengawasan Pejabat Karantin. 
3. Saat Keberangkatan Kapal :

a. Sebelum keberangkatan Kapal, Nakhoda wajib melengkapi Dokumen Karantina Kesehatan yang masih berlaku.

b. Setelah Dokumen Karantina Kesehatan dinyatakan lengkap dan pada pemeriksaan oleh Pejabat Karantina Kesehatan tidak ditemukan indikasi Faktor Risiko Kesehatan Masyarakat maka kepada Nakhoda dapat diberikan Surat Persetujuan Berlayar Karantina Kesehatan (Port Health Quarantine Cle arancel).

c. Dalam hal Kapal yang akan berangkat tidak dilengkapi dengan Surat Persetujuan Berlayar Karantina Kesehatan (Port Health Quarantine Clearance)dengan ketentuan :

1) Syahbandar dilarang menerbitkan surat persetujuan berlayar.

2) Apabila pada saat keberangkatan Kapal ditemukan adanya Faktor Risiko Kesehatan Masyarakat maka terhadap Kapal tersebut dilakukan tindakan Kekarantinaan.

d. Untuk Pelabuhan yang tidak memungkinkan dilakukan tindakan Kekarantinaan Kesehatan maka harus dilakukan di Pelabuhan tujuan berikutnya.

\section{KESIMPULAN}

Dari analisa di lapangan ditemukan bahwa adanya waktu delay kapal sandar dikarenakan adanya pemeriksaan coviq-19 terhadap crew kapal dengan metode rapid test. Waktu tunggu ini akan bertambah panjang apabila ditemukan salah satu crew yang reaktif dan harus melakukan swap test lanjutan yang memerlukan waktu 3 hari sampai menunggu hasil test tersebut dan crew yang lainnya akan diisolasi sampai menunggu hasil pengetesan crew yang positif dan juga disinfektan kapal yang telah terjangkit Covid-19 guna mencegah penyebaran virus Covid-19 di pelabuhan. Selain itu, setiapperusahaanpelayaranatau perusahaan yang mengoperasikan kapal (Ship Management) harus menjabarkan dari UndangUndang Republik Indonesia Nomor. 6 Tahun 2018 Tentang Kekarantinaan Kesehatan, melalui Organisasi internal perusahaan penanggulangan Covid-19 untuk melakukan koordinasi dengan keagenan kapal maupun Satgas Covis-19 setiap pelabuhan. Agar proses kedatangan dan keberangkatan kapal berjalan lancar. Satgas Covid-19 internal perusahaan harus selalu update tetantang peraturan atau kebijakan terbaru yang diterapkan disetiap pelabuhan, terutama informasi berkelanjutan yang diinformasikan oleh Kantor Kesehatan Pelabuhan (KKP) dan Satgas Covid-19 pelabuhan setempat. Nakhoda merupakan kepanjangan tangan dan bagian dari tim covid-19 internal perusahaan dalam berkoordinasi dengan keagenan, KKP dan KSOP guna kelancaran penyandaran maupun keberangkatan.

Hal tersebut mempengaruhi kinerja proses penyandaran kapal sandar dengan beberapa masalah sebagai berikut : Bertambahnya Proses Birokrasi Instansi pemeriksaan kesehatan pada karantina kesehatan pelabuhan atas 
peraturan prosedur pengawasan kekarantinaan kesehatan pelabuhan; Waktu tunggu sandar kapal akanbertambah panjang dengan adanya Pandemi Covid-19; Kapal tidak bisa bekerja maximal bila ditemukan crew kapal terjangkit virus Covid-19, secara otomatis akan berpengaruh pada biaya tambat kapal saat loading dan Unloading cargo; Efektifitas kapal akan sedikit terganggu dengan adanya protol kesehatan di masa transisi (new normal) yang ada.

\section{DAFTAR PUSTAKA}

Azanella LA,(2020), Panduan Protokol Lsehatan Covid -19 untuk sambut New Normal,https://www.kompas.com/tren/read/2020/05/18/103200465/simakpanduan-protokol-kesehatan-pencegahan-covid-19-untuk-sambutnew page $=$ all.Diakses $:$ Padatanggal 14 Desember 2020

Berita Terkini | Satgas Penanganan Covid-19. (n.d.). Retrieved February 20, 2021, from https://covid19.go.id/berita/pasien-sembuh-covid-19mencapai-lebih-dari-10-ribu-hari

Keputusan Menteri Kesehatan Republik Indonesia Nomor Hk.01.07/Menkes/328/2020 Tentangpanduan Pencegahan Dan Pengendalian Corona Virus Disease 2019 (Covid-19) Di Tempat Kerja Perkantoran Dan Industri Dalam Mendukung Keberlangsungan Usaha Pada Situasi Pandemi

Kwartama Agung, Veronika Risa Fatika, Indriawan Didik. Pengantar Manajemen Pelayaran Niaga.Jakarta. Djangkar.

Surat Edaran Nomor UM. 001/09/19/KSOP.Tjng. Emas-2020 Tentang Penetapan Area Karantina di Dermaga, (2020).

Peraturan Menteri Perhubungan No. KM.21 Tahun 2007 tentang Sistem dan Prosedur Pelayanan Kapal, Barang, dan Penumpang pada Pelabuhan Laut yang diselenggarakan oleh Unit Pelaksana Teknis (UPT) kantor pelabuhan, (2007).

Salim, A. (1993). Manajemen Transportasi. PT.Raja Grafindo Persada.

Undang-Undang Republik Indonesia Nomor 21 Tahun 1992 , Tentang Pelayaran, Pasal 1, (1992).

Undang-Undang Republik Indonesia Nomor. 6 Tahun 2018 Tentang Kekarantinaan Kesehatan, (2018).

https://news.detik.com/berita/d-5168680/bahas-tantangan-transportasi-laut-iniyang-dilakukan-kemenhub. Diakses :padatanggal 16 Desember 2020

https://covid19.go.id/berita/pasien-sembuh-covid-19-mencapai-lebih-dari-10ribu-hari 